\title{
Lectin detection of cell surface saccharides remodeling induced by development of P-glycoprotein mediated multidrug resistance phenotype in L1210 leukemia cells
}

\author{
Mário Šereša , Lucia Pavlíkováa, Zdena Sulováa , Albert Breier ${ }^{\mathrm{b}}$ \\ ${ }^{a}$ Institute of Molecular Physiology and Genetics, Slovak Academy of Sciences, \\ Vlárska 5, 83334 Bratislava, Slovak Republic, mario.seres@savba.sk \\ ${ }^{b}$ Institute of Biochemistry, Nutrition and Health Protection, \\ Faculty of Chemical and Food Technology, \\ Slovak University of Technology in Bratislava, \\ Radlinského 9, 81237 Bratislava, Slovak Republic
}

\begin{abstract}
P-glycoprotein is an ATP dependent drug efflux pump the expression of which is responsible for strong depression of cell sensitivities to large group of structurally unrelated substances in neoplastic cells. We found that the expression of this protein in mice leukemia cells L1210 is associated with massive remodeling of cell surface saccharides. This remodeling is consistent with the alteration of cellular contents of UDP-sugars, glycogen and glycoproteins when P-gp positive and P-gp negative L1210 cell variants were compared. The current paper is focused on bringing the state of art information about this topic.
\end{abstract}

\section{Introduction}

Multidrug resistance (MDR) of neoplastic cells represents an obstacle in the effective treatment of cancer by chemotherapy (Perez-Tomas 2006). Overexpression of the plasma membrane ABCB1 transporter (known as P-glycoprotein - P-gp), represents the most frequent molecular cause of MDR phenotype development observed (reviewed in: Breier et al. 2013). P-gp is a plasma membrane efflux pump with broad substrates specificity to a large group of structurally unrelated substances, including vincristine, doxorubicin, mitomycin $\mathrm{C}$, actinomycin $\mathrm{D}$, cyclophosphamide and dexamethasone and many others (Breier et al. 2000). This protein is encoded by the $m d r 1(a b c b 1)$ gene and is member of ABC transporters gene family. Each molecule of P-gp contains two nucleotide binding domains with the $\mathrm{ABC}$ consensus motif and two transmembrane domains that consist of six $\alpha$-helical membrane spans (reviewed in: Breier et al. 2005). While expressed in neoplastic cells, P-gp induced cell resistance to large group of anticancer drugs. Overexpression of P-glycoprotein could be induced in neoplastic cells by selective pressure of anticancer drugs/P-gp-substrates. P-gp expression is transcriptionally controlled by nuclear receptors that responded to the presence of xenobiotics as ligands in intracellular space (reviewed in: Breier et al. 2005). While the activation of pregnane $\mathrm{X}$ and constitutive androstane nuclear receptors has been described to induce P-gp transcription (Červený et al. 2007), also receptors for retinoids play a partial role in this process (Sulová et al. 2012; Sulová et al. 2008).

\section{P-glycoprotein glycosylation}

$\mathrm{P}$-gp is synthesized as a $145-\mathrm{kDa}$ polypeptide that is later glycosylated to a final molecular weight in range 170-180 kDa (Šereš et al. 2011). The glycosylation occurs on the first intracellular loop of Pglycoprotein on asparagines 91, 94 and 99 (Gribar et al. 2000). There are broad variability in glycosides linked to $\mathrm{P}$-glycoprotein via $\mathrm{N}$-glycosylation pattern (Greer et al. 2007). Massive expression of P-glycoprotein in the plasma membrane leads to the exposure of additive P-gp-linked glycosides, which alters the composition of cell surface sugars. However glycosylation of P-gp was not found to be necessary for the plasma membrane localization and the drug transport activity of P-gp in L1210 cells (Šereš et al. 2011). In contrast, Loo et al. (1998) described P-gp glycosylation as important factor for proper quality control of P-gp in the endoplasmic reticulum and for P-gp maturation. Proper integration of P-gp to the plasma membrane was assumed to be directed by effective glycosylation (Schinkel et al. 1993). Tunicamycin (Fig. 1) is generally known to inhibit the process of protein $\mathrm{N}$-glycosylation in the endoplasmic reticulum by blocking the transfer of $\mathrm{N}$-acetylglucosamine-1-phosphate from uridine diphosphate- $N$-acetyl-glucosamine to dolichol phosphate (Bretthauer 2009).

Tunicamycin was described to induce an elevation of P-gp expression (at both the mRNA and protein levels) and efflux activity in Fao hepatoma cells (Ledoux et al. 2003). When glycosylation of Pglycoprotein is effectively blocked by tunicamycin (Šereš et al. 2011) core glycosylated P-gp was still 


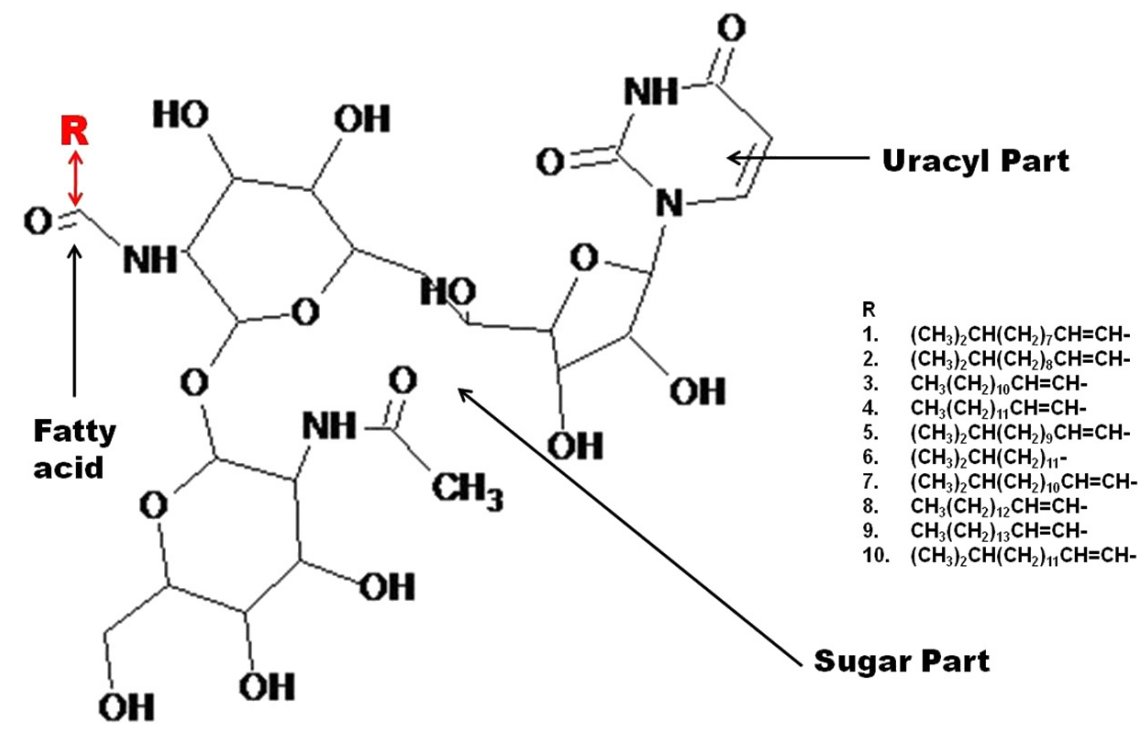

Fig. 1. Tunicamycin represent group of ten analogues differ in structure of aliphatic chain $\mathrm{R}$ in fatty acid part of molecule.

L1210/VCR
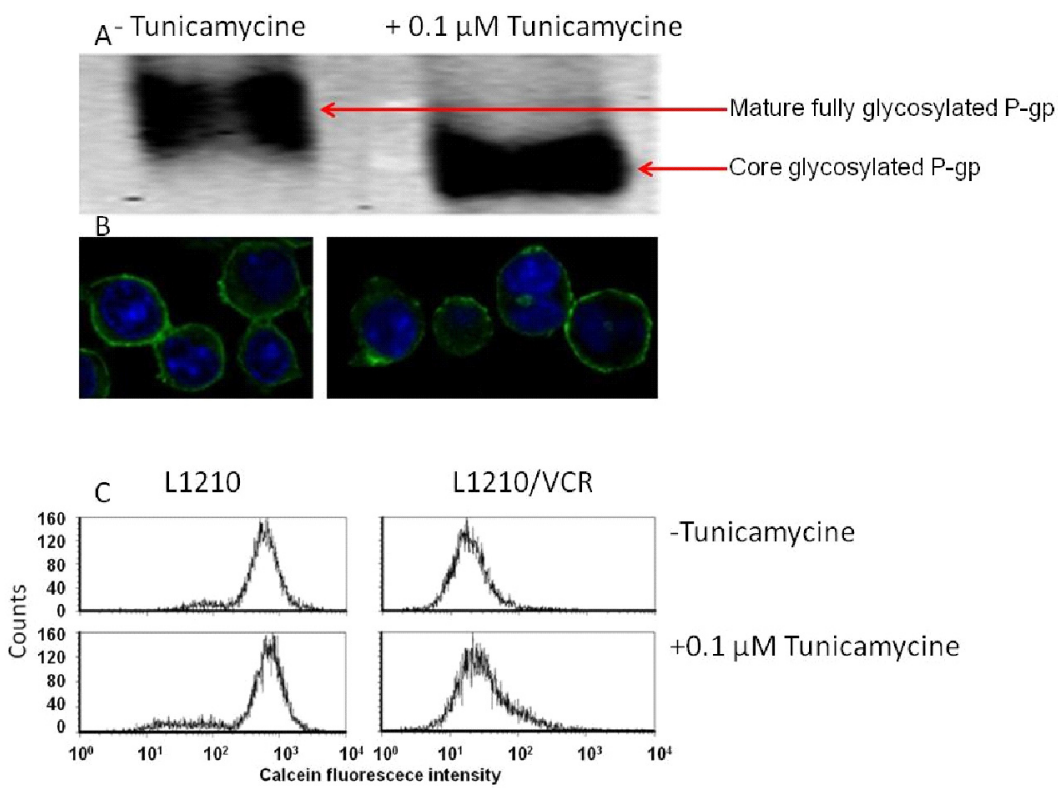

Fig. 2. Effect of tunicamycin on glycosylation, membrane expression and efflux activity of P-gp in mice leukemia L1210 cells. Cells: L1210 - parental P-gp-negative cells. L1210/VCR - P-gp-positive cells that express P-gp due to selective pressure of vincristine. Panel A: Western blot analysis of tunicamycin effect on P-gp glycosylation. P-gp was detected by monoclonal anti-P-gp antibody c219 and rabbit anti-mouse antibody linked with horse radish peroxidase. Only core glycosylated P-gp with $\mathrm{M}_{\mathrm{r}}$ not exceeding $160 \mathrm{kDa}$ is present in L1210/VCR cells after cultivation with tunicamycin. Panel B: Effect of tunicamycin on membrane localization of P-gp in L1210 cells. Cells were permeabilized by incubation in methanol at $-20^{\circ} \mathrm{C}$. Nuclei were stained by $4^{\prime}$-6-diamidino-2-phenylindole (blue color); P-gp (green color) was visualized with c219 antibody and goat antimouse antibody linked with fluorescein isothiocyanate as primary and secondary antibody. Tunicamycin did not alter plasma membrane localization of P-gp. Pictures were obtained using confocal laser scanning microscope (LSM 510 META Carl Zeiss). Panel C: Effect of tunicamycin on P-gp efflux activity estimated by Calcein retention assay. Massive calcein retention is observed on L1210 cells. P-gp efflux activity is depressing calcein retention in L1210/VCR cells. Tunicamycin did not alter calcein retention in L1210 and L1210/VCR cells, i.e., did not alter P-gp efflux activity. Fluorescence was measured on BD Accuri C6 flow cytometer (BD Bioscience, San Jose,

$$
\text { CA, USA). }
$$


localized in plasma membrane and exerted full transmembrane efflux activity (Fig. 2).

In contrast to our observation, inhibition of P-gp $\mathrm{N}$-glycosylation by tunicamycin leads to increased ubiquitination and the subsequent degradation of P-gp in several P-gp positive cell lines derived from solid tumors via drug selection or transfection with the gene encoding P-gp (Zhang et al. 2004). Thus, tunicamycin may induce either an increase or decrease in drug resistance associated with an improvement or impairment of P-gp function, respectively. This dual effect of tunicamycin seems to be due to differences between cell types. Specific glycosylation of P-glycoprotein could be detected in the plasma membrane of P-gp positive cells by several lectins, such as Galanthus nivalis agglutinin (GNA) and Sambucus nigra agglutinin (SNA), using lectin blot procedure (Bubenčíková et al. 2012; Greer and Ivey 2007; Šereš et al. 2011). However, after tunicamycin treatment of P-gp positive L1210 cells, non-glycosylated P-gp could not be detected by either of these lectins (Šereš et al. 2011).

\section{Alteration of protein glycosylation associated with $P$-gp overexpression in L1210 cells.}

Overexpression of $\mathrm{P}$-gp in mice leukemia cells L1210/VCR was found to be associated with depression of UDP-sugars cell contents that is reflected by a decrease in glycogen and glycoprotein cell contents as compared with parental P-gp negative cells (Fiala et al. 2003). Cells surface glycosides contain acidic sugars (like sialic acid) that may play a role in bivalent cation (predominantly $\mathrm{Ca}^{2+}$ ) chelating on cell surface (Bonilla et al. 1987). Negatively charged carboxyl groups of sialic acid and other acidic sugars on the cell surface was described to bound electron dense cationic dye ruthenium red (RR) that enable visualization in electron microscope (Berg et al. 2009; Fiala et al. 2003; Uhrík et al. 2006).

Surface of P-gp negative L1210 cells bound considerably larger amounts of RR than P-gp positive counterparts L1210/VCR (Fiala et al. 2003; Uhrík et al. 2006). The compact layer of bound RR is observable on plasma membrane profile of L1210 cells (Fig. 3). In contrast plasma membrane profile of L1210/VGR cells is much less stained by RR.

These data indicated that negatively charged functional groups of glycoside origin were reduced on surface of the plasma membrane of P-gp positive L1210 cells (Fiala et al. 2003; Uhrík et al. 2006). Luft (1971a, b) assumed that negatively charged cell surface is predominately formed by sialic acid (SA). Decrease in the number of negative binding sites in the lamina externa of resistant cells is not only a sign of an alteration in oligo- and poly-saccharide metabolism but may be related also to changes in cellular aggregation, whereas resistant cells tend to form clusters (Uhrík et al. 2006). This tendency to aggregate may be determined by changes in the number and distribution of negative charges in the glycocalyx or the expression of adhesion molecules (Vitte et al. 2005). All the above facts indicated that P-glycoprotein mediated multidrug resistance development in L1210 cells induced a massive remodeling of cell surface materials. This is consistent with glycomic alterations associated with multidrug resistance in human leukemia cells described by Zhang et al. (2012).

\section{Application of lectins in characterization of surface sugars alteration associated with $P$-gp expression in L1210 cells}

Lectins are sugars binding proteins that can be used for studying of alteration cell surface saccharides (Mislovičová et al. 2009). Ability of lectins to recognize carbohydrates with appropriate specificity to unique structural feature of different sugar moieties predetermine their application to wide spectrum of utilization. Plants lectins are known to play defense role against attack of bacteria, viruses, pests and insects (Peumans et al. 1995). However, some lectins could be dangerous also for human, because they are resistant to digestion and are able to damage gut epithelia, enter to blood and agglutinate blood cells. Further they could

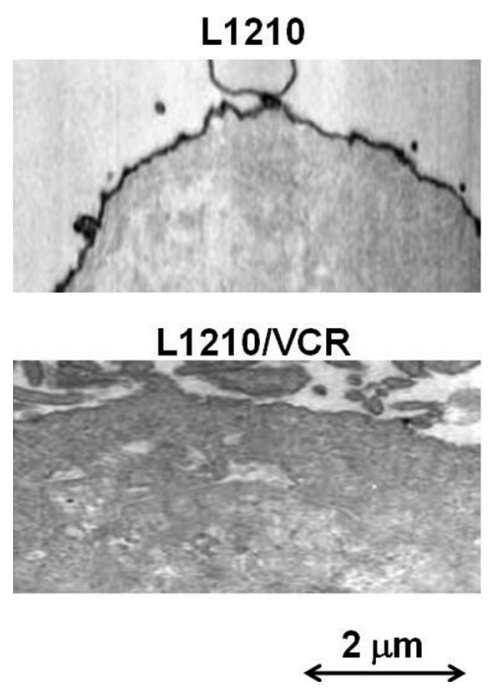

Fig. 3. Visualization of negatively charged cell surface material by ruthenium red. L1210 cells contains compact layer of bound ruthenium red attached on plasma membrane. In contrast staining of membrane profile of L1210/VGR cells by RR is much less pronounced. Pictures were obtained using JEOL JEM-1200 EX electron microscope at $80 \mathrm{kV}$. 
play important role in immune system cell grow and cell dead. On the other hand, lectins could be considered as appropriate tools for monitoring of changes in spectra of glycosides present on surface of cell plasma membrane associated with transformed cell metabolism during cancer development (Murase et al. 1984). It could be also applicable for monitoring of surface glycosides alteration during P-gp mediated MDR development (reviewed in Breier et al. 2013).

Fact that resistance of L1210 cells to vincristinecolchicine is associated with depression in cell agglutinability by concanavalin A (ConA) was documented 38 year ago (Csuka et al. 1976). In our previous papers (Sulová et al. 2010; Sulová et al. 2009), we bring the evidence that depression of ConA binding to surface sugars in L1210 cells is directly associated with the presence of P-gp in L1210/VCR cells. In contrast to ConA, tomato lectin LEA (Lycopersicum Esculentum Agglutinin) was bounded P-gp positive L1210/VCR cells more potently than to P-gp negative counterparts (Sulová et al. 2009). Both ConA and LEA, in contrast to SNA and GNA that interact directly with the P-gp linked saccharides (Bubenčíková et al. 2012; Šereš et al. 2011), fails to detect P-gp in lectin blots (Sulová et al. 2010; Sulová et al. 2009). A similar depression of ConA binding as was observed on cell surface of L1210/VCR cells was also present in other P-gp positive L 1210/T cell variant obtained by transfection of L1210 cells with the human gene encoding P-gp (Sulová et al. 2010). Therefore, depression of ConA saccharide ligands exposure on the surface of P-gp positive L1210 cells (L1210/VCR, L1210/T) is directly associated with presence of $\mathrm{P}$-gp in cells as secondary cellular response on massive expression of this protein. All the above data indicated on massive remodeling of cell surface saccharides that is associated with $\mathrm{P}$-gp expression in $\mathrm{P}$-gp positive cells. These changes include also differences in the exposure of negatively charged functional groups (probably SA) on the plasma membrane. Therefore, we were aimed to study the interaction between the cell surface of P-gp negative and P-gp positive cells with following lectin which are known as SA-specific lectins (Lehmann et al. 2006): i. SNA; ii. WGA (wheat germ agglutinin); iii. MAA (Maackia amurensis agglutinin). We found massive binding of SNA to all variants of L1210 cell surfaces that indicates on SA linkage to cell surface via a-2, 6 branched sugars (Bubenčíková et al. 2012). Binding of MAA that recognize of $\alpha-2,3$ branched SA (Table 1) was much less pronounced. Similarly than LEA, also WGA gave stronger interaction with P-gp positive L1210/VCR and L1210/T than with P-gp negative L1210 cells (Table 1). This indicated on the improvement of contents in internal $\mathrm{N}$-acetyl-glucosamine in P-gp positive L1210/VCR and L1210/T cells as compared with parental L1210 cells. P-gp expression induced alteration in biding of different lectins to cell surface of P-gp positive cells are summarized in Table (1). P-gp positive L1210/VCR and L1210/T cells interact more efficiently with LEA, WGA and MAA and oppositely less efficiently with ConA and SNA than P-gp negative L1210 cells.

Tab. 1. Interaction of lectins with cell surface of P-gp positive L1210 cells.

\begin{tabular}{llccl}
\hline Lectin & Specificity & L1210/VCR & L1210/T & Ref \\
\hline ConA & Internal nonreducing terminals & $\downarrow \downarrow$ & $\downarrow \downarrow$ & (Sulová et al. 2010; Sulová et al. 2009) \\
& Man- > Glc- & & & \\
LEA & GlcNAc oligomers & $\uparrow$ & ND & (Sulová et al. 2009) \\
WGA & Internal GlcNAc > GlcNAc - SA > & $\uparrow \uparrow$ & $\uparrow \uparrow$ & (Bubenčíková et al. 2012) \\
& GalNAc > Lac> Gal & & & \\
MAA & $\alpha-2,3$ branched SA & $\uparrow$ & $\uparrow$ & (Bubenčíková et al. 2012) \\
SNA & $\alpha-2,6$ branched SA & $\downarrow$ & $\downarrow$ & (Bubenčíková et al. 2012)
\end{tabular}

$\downarrow \downarrow-$ Strong depression of lectin binding to cell surface of P-gp positive cells in comparison with P-gp negative L1210 cells.

$\downarrow \quad-$ Mediate depression of lectin binding to cell surface of P-gp positive cells in comparison with P-gp negative L1210 cells.

$\uparrow \uparrow$ — Strong elevation of lectin binding to cell surface of P-gp positive cells in comparison with P-gp negative L1210 cells.

$\uparrow \quad-\quad$ Mediate elevation of lectin binding to cell surface of P-gp positive cells in comparison with P-gp negative L1210 cells.

Abbreviations: GlcNAc - $\beta$-D-N-acetyl glukosamine; GalNAc - N-acetyl galaktosamine; Lac - lactose; Gal - Galactose; Man- - $\alpha$-D-mannosyl groups; Glc- $-\alpha$-D-glucosyl groups. 


\section{Conclusions}

Experiments with lectins revealed strong remodeling of cell surface sugars in L1210 cells that overexpress P-gp. The fact that independently on way of P-gp expression (selection with vincristine or transfection with human gene encoding P-gp), presence of this protein in the cells induced changes in the composition of plasma membrane-bound saccharides of L1210 cells. These indicated that presence of P-gp alone in L1210/VCR and L1210/T cells is responsible for changes in cell surface sugars detectable by several lectins. Therefore, the alteration in membrane bound saccharide-targets of lectins in L1210/ VCR and L1210/T cells as compared with L1210 cells may be considered as secondary cellular response to P-gp overexpression. This is relatively surprising fact. Since exposure of specific sugars on cell surface is believed to be related to differentiation status of cells (Pepperl et al. 1993) it could be speculated that P-gp overexpression in lymphocytic L1210 cells induced changes of their differentiation status. This is consistent with fact that P-gp is expressed in primitive CD34 positive bone narrow stem cells (Licht et al. 1994), i.e. in non-differentiated cells that could developed to several types of blood cells during the hematopoiesis.

\section{Acknowledgement}

This research was supported by grants from the Centre of excellence for glycomics, ITMS 26240120031 supported by the Research \& developmental Operational Programme funded by the ERDF and VEGA 2/0100/12.

\section{References}

Berg KD, Tamas RM, Riemann A, Niels-Christiansen LL, Hansen GH, Michael Danielsen E (2009) Histochem Cell Biol 131: 103-114.

Bonilla E, Moggio M (1987) Histochemistry 86: 503-507. Breier A, Barančík M, Sulová Z, Uhrík B (2005) Curr Cancer Drug Targets 5: 457-468.

Breier A, Drobna Z, Docolomansky P, Barančík M (2000) Neoplasma 47: 100-106.

Breier A, Gibalová L, Šereš M, Barančík M, Sulová Z (2013) Anticancer Agents Med Chem 13: 159-170.

Bretthauer RK (2009) Curr Drug Targets 10: 477-482.

Bubenčíková T, Cholujová D, Messingerová L, Mislovicová D, Šereš M, Breier A, Sulová Z (2012) Int J Mol Sci 13: 15177-15192.

Červený L, Švecová L, Anzenbacherová E, Vrzal R, Staud F, Dvořák Z, Ulrichová J, Anzenbacher P, Pavek P (2007) Drug Metab Dispos 35: 1032-1041.
Csuka O, Sugar J (1976) Acta Morphol Acad Sci Hung 24: 297-305.

Fiala R, Sulová Z, El-Saggan AH, Uhrík B, Liptaj T, Dovinová I, Hanušovská E, Drobná Z, Barančík M, Breier A (2003) Biochim Biophys Acta 1639: 213-224.

Greer DA, Ivey S (2007) Biochim Biophys Acta 1770: $1275-1282$.

Gribar JJ, Ramachandra M, Hrycyna CA, Dey S, Ambudkar SV (2000) J Membr Biol 173: 203-214.

Ledoux S, Yang R, Friedlander G, Laouari D (2003) Cancer Res 63: 7284-7290.

Lehmann F, Tiralongo E, Tiralongo J (2006) Cell Mol Life Sci 63: 1331-1354.

Licht T, Pastan I, Gottesman M, Herrmann F (1994) Ann Hematol 69: 159-171.

Loo TW, Clarke DM (1998) J Biol Chem 273: 3237332376.

Luft JH (1971a) Anat Rec 171: 347-368.

Luft JH (1971b) Anat Rec 171: 369-415.

Mislovičová D, Gemeiner P, Kozárová A, Kozár T (2009) Biologia 64: 1-19.

Murase N, Takai Y, Hosaka M, Asano K, Mori M (1984) J Oral Pathol 13: 505-515.

Pepperl B, Bohn B, Sauer A, Brossmer R (1993) Cell Biophys 23: 165-185.

Perez-Tomas R (2006) Curr Med Chem 13: 1859-1876.

Peumans WJ, Van Damme EJ (1995) Plant Physiol 109: 347-352.

Šereš M, Cholujová D, Bubenčíková T, Breier A, Sulová Z (2011) Int J Mol Sci 12: 7772-7784.

Schinkel AH, Kemp S, Dolle M, Rudenko G, Wagenaar E (1993) J Biol Chem 268: 7474-7481.

Sulová Z, Brtko J, Macejová D, Breier A (2012) In: Cheng L-H, It Y (eds) Retinoic Acid: Structure, Mechanisms and Roles in Disease. NOVA Publisher, pp 29-52; online on: https://www.novapublishers.com/catalog/ product_info.php?products_id=34515.

Sulová Z, Ditte P, Kurucová T, Poláková E, Rogozanová K, Gibalová L, Šereš M, Škvarková L, Sedlák J, Pastorek J, Breier A (2010) Anticancer Res 30: 3661-3668.

Sulová Z, Macejová D, Šereš M, Sedlak J, Brtko J, Breier A (2008) Toxicol In Vitro 22: 96-105.

Sulová Z, Mislovičová D, Gibalová L, Vajcnerová Z, Poláková E, Uhrík B, Tylková L, Kovárová A, Sedlák J, Breier A (2009) J Proteome Res 8: 513-520.

Uhrík B, El-Saggan AH, Šereš M, Gibalová L, Breier A, Sulová Z (2006) Gen Physiol Biophys 25: 427-438.

Vitte J, Benoliel AM, Pierres A, Bongrand P (2005) Clin Hemorheol Microcirc 33: 167-188.

Zhang Z, Wu JY, Hait WN, Yang JM (2004) Mol Pharmacol 66: 395-403.

Zhang Z, Zhao Y, Jiang L, Miao X, Zhou H, Jia L (2012) Int J Biochem Cell Biol 44: 1244-1253. 